\title{
Receptor-mediated release of inositol phosphates in the cochlear and vestibular sensory epithelia of the rat
}

\author{
Kaoru Ogawa and Jochen Schacht \\ Kresge Hearing Research Institute, University of Michigan, Ann Arbor, Michigan, USA
}

(Received 19 January 1993; Revision received 3 May 1993; Accepted 7 May 1993)

\begin{abstract}
Various neurotransmitters, hormones and other modulators involved in intercellular communication exert their biological action at receptors coupled to phospholipase $\mathrm{C}$ (PLC). This enzyme catalyzes the hydrolysis of phosphatidylinositol 4,5-bisphosphate (PtdIns $\mathrm{P}_{2}$ ) to inositol 1,4,5-trisphosphate ( $\mathrm{Ins}_{3}$ ) and 1,2-diacylglycerol (DG) which act as second messengers. In the organ of Corti of the guinea pig, the InsP $\mathrm{P}_{3}$ second messenger system is linked to muscarinic cholinergic and $\mathrm{P}_{2} \mathrm{y}$ purinergic receptors. However, nothing is known about the the Ins $\mathrm{P}_{3}$ second messenger system in the vestibule. In this study, the receptor-mediated release of inositol phosphates (InsPs) in the vestibular sensory epithelia was compared to that in the cochlear sensory epithelia of Fischer-344 rats. After preincubation of the isolated intact tissues with myo- $\left[{ }^{3} \mathrm{H}\right] \mathrm{in}$ ositol, stimulation with the cholinergic agonist carbamylcholine or the $\mathrm{P}_{2}$ purinergic agonist ATP- $\gamma$-S resulted in a concentration-dependent increase in the formation of $\left[{ }^{3} \mathrm{H}\right]$ InsPs in both epithelia. Similarly, the muscarinic cholinergic agonist muscarine enhanced InsPs release in both organs, while the nicotinic cholinergic agonist dimethylphenylpiperadinium (DMPP) was ineffective. The muscarinic cholinergic antagonist atropine completely suppressed the InsPs release induced by carbamylcholine, while the nicotinic cholinergic antagonist mecamylamine was ineffective. Potassium depolarization did not alter unstimulated or carbamylcholine-stimulated release of InsPs in either organ. In both tissues, the $\mathrm{P}_{2}$ purinergic agonist $\alpha, \beta$-methylene ATP also increased InsPs release, but the $\mathrm{P}_{1}$ purinergic agonist adenosine did not. These results extend our previous obscrvations in the organ of Corti of the guinea pig to the rat and suggest a similar control of the Ins $P_{3}$ second messenger system in the vestibular sensory epithelia. In contrast to the cochlear sensory epithelia, atropine also significantly suppressed unstimulated InsPs release in the vestibular sensory epithelia. This suggests that the physiological mechanisms of the efferent nervous systems involving Ins $P_{3}$ second messenger system might be different in vestibular versus cochlear sensory epithelia.
\end{abstract}

Inositol phosphates; Second messenger; Cochlea; Vestibule; Muscarinic cholinergic receptor; Purinergic receptor; Rat

\section{Introduction}

The activation of phospholipase $\mathrm{C}$ (PLC) is the metabolic step regulated by many neurotransmitters, hormones and other modulators involved in intercellular communication. The plasma membrane receptors of these agents are coupled to this enzyme which catalyzes the hydrolysis of phosphatidylinositol 4,5-bisphosphate $\left(\mathrm{PtdIns}_{2}\right)$ into inositol 1,4,5-trisphosphate (Ins $\mathrm{P}_{3}$ ) and 1,2-diacylglycerol (DG). Both InsP $_{3}$ and $\mathrm{DG}$ then act as intracellular second messengers. InsP raises calcium levels by releasing calcium ions from intracellular stores such as the endoplasmic reticulum, while DG activates calcium-dependent protein kinase C. These two events result in protein phosphorylation which regulates enzyme activities and a variety of physiological cellular responses including intermediary metabolism, cell motility, ion channels and neurotrans-

Correspondence to: Jochen Schacht, Kresge Hearing Research Institute, University of Michigan, 1301 East Ann Street, Ann Arbor, MI 48109-0506, USA. Fax: (313) 764-0014. mitter synthesis and release (Nishizuka, 1984; Berridge and Irvine, 1984).

The Ins $\mathrm{P}_{3}$ second messenger system is present in the cochlea and coupled to muscarinic cholinergic and $P_{2} y$ purinergic receptors as determined from studies of phosphoinositide metabolism and release of $\operatorname{InsP}_{3}$ (Orsulakova et al., 1976; Schacht and Zenner, 1986, 1987; Ono and Schacht, 1989; Bartolami et al., 1990; Guiramand et al., 1990; Wang and Schacht, 1990; Niedzielski and Schacht, 1991, 1992; Niedzielski et al., 1992). The expression of the appropriate muscarinic receptor subtypes $\mathrm{m} 1, \mathrm{~m} 3$ and $\mathrm{m} 5$ was also recently documented in cochlear tissues (Drescher et al., 1992). However, the precise localization and function of the phosphoinositide second messenger system in the cochlea remains largely speculative. Given its involvement in diverse aspects of cellular physiology, multiple sites and actions can be expected. Indeed, components of this second messenger system have so far been found in the lateral wall tissues (Orsulakova et al., 1976), hair cells (Tachibana et al., 1985; Schacht and Zenner, 1987) and Deiters' cells (Dulon et al., 1993). Because of the participation of calcium in slow shape 
changes of isolated outer hair cells (Zenner, 1986; Flock et al., 1986; Dulon et al., 1990), it has been speculated that phosphoinosites may regulate 'slow motility' via release of $\mathrm{InsP}_{3}$ and elevation of intracellular calcium (Schacht and Zenner, 1987; Dulon and Schacht, 1992). Application of InsP $P_{3}$ to permeabilized cells indeed elicited a slow motile response of outer hair cells (Schacht and Zenner, 1986, 1987). Whether or not acetylcholine, the presumed cochlear efferent neurotransmitter, can elicit motile responses (via activation of muscarinic receptors and the $\operatorname{InsP}_{3}$ cascade) remains controversial (see Bobbin et al., 1990; Dulon and Schacht, 1992).

The vestibular sensory epithelia consist of the macula utriculi, macula sacculi and cristae ampullares of semicircular canals. Two types of hair cells are present in these epithelia. Type I hair cells are flask-shaped and surrounded by an afferent nerve calice that receives efferent innervations, while type II hair cells are cylindrical and innervated directly by the afferent and efferent nerves. Several morphological and physiological observations have led to the speculation that the vestibular hair cells might also possess an active motility (Sans et al., 1989; Zenner et al., 1990; Valat et al., 1991, Lepyre and Cazals, 1991). The functional similarities of cochlear and vestibular hair cells as mechanoreceptors and their motile properties suggest that the Ins $P_{3}$ second messenger system might also exist in the vestibule. However, nothing is known about the $\operatorname{Ins} \mathrm{P}_{3}$ second messenger system in these tissues. In the present paper, we compare receptor-mediated release of InsPs in the vestibular sensory epithelia to that in the cochlear sensory epithelia. These results have been presented in a preliminary report (Ogawa and Schacht, 1993).

\section{Materials and Methods}

\section{Materials}

Fischer-344 rats (3 month-old, male; from Charles River, Kingston, NY) with a positive Preyer reflex were used in this study. Myo- $\left[{ }^{3} \mathrm{H}\right]$ inositol (specific activity, $82 \mathrm{Ci} / \mathrm{mmol}$ ) was obtained from Amersham Corporation (Arlington Heights, IL) and Hanks' balanced salt solution from Gibco BRL Life Technologies Inc. (Gaithersburg, MD). All other reagents were purchased from Sigma (St. Louis, MO).

\section{Tissue preparation}

The otic capsules were quickly removed following decapitation and placed in incubation buffer at room temperature. The incubation buffer was a Hanks' balanced salt solution $(137.9 \mathrm{mM} \mathrm{NaCl}, 5 \mathrm{mM} \mathrm{KCl}, 1.3$ $\mathrm{mM} \mathrm{CaCl} 2,0.3 \mathrm{mM} \mathrm{KH}_{2} \mathrm{PO}_{4}, 5 \mathrm{mM} \mathrm{MgCl}, 0.4 \mathrm{mM}$ $\mathrm{MgSO}_{4}, 0.3 \mathrm{mM} \mathrm{NaH}{ }_{2} \mathrm{PO}_{4}, 5.6 \mathrm{mM} \mathrm{D}$-glucose) with 5
$\mathrm{mM}$ sodium $\mathrm{N}-2$ hydroxyethylpiperazine- $\mathrm{N}^{\prime}-2$ ethane sulfonic acid (HEPES). The buffer was gassed with $95 \% \mathrm{O}_{2}$ and $5 \% \mathrm{CO}_{2}$ for $30 \mathrm{~min}$ prior to use, and then its $\mathrm{pH}$ was adjusted to 7.4 with $\mathrm{NaOH}$ and its osmolality to $300 \pm 2$ mOsm with $\mathrm{NaCl}$. The cochlear sensory epithelia (including inner and outer hair cells, supporting cells, basilar membrane and lateral part of the spiral limbus) and the vestibular sensory epithelia (including macula utriculi, macula sacculi and cristae ampullares of semicircular canals) were isolated by microdissection and transferred into the incubation buffer.

\section{Assay of phosphoinositide hydrolysis}

In order to label the inositol lipid pool, tissues were incubated for $2 \mathrm{hr}$ at $37^{\circ} \mathrm{C}$ in $50 \mu \mathrm{l}$ of buffer with $1 \mathrm{mM}$ cytidine and $16 \mu \mathrm{Ci}$ myo- $\left[{ }^{3} \mathrm{H}\right]$ inositol (specific activity, $82 \mathrm{Ci} / \mathrm{mmol}$ ) as described previously (Niedzielski and Schacht, 1991). After removing the myo- $\left[{ }^{3} \mathrm{H}\right]$ inositolcontaining incubation medium and washing twice with $0.5 \mathrm{ml}$ of radioactivity-free buffer, $90 \mu \mathrm{l}$ of buffer with $10 \mathrm{mM} \mathrm{LiCl}$ was added and incubation continued for $10 \mathrm{~min}$. Then, $10 \mu \mathrm{l}$ of buffer with cholinergic or purinergic agonists, antagonists or both of them were added. For potassium depolarization, a potassium chloride/Hanks' balanced salt solution (sodium replaced by potassium) with $5 \mathrm{mM}$ HEPES was added $(50 \mathrm{mM}$ $\mathrm{KCl}$ final concentration). After $30 \mathrm{~min}$ at $37^{\circ} \mathrm{C}$, phosphoinositide hydrolysis was terminated by the addition of $300 \mu \mathrm{l}$ of chloroform/methanol $(1: 2, \mathrm{vol} / \mathrm{vol})$. In order to separate aqueous and chloroform phases, 100 $\mu \mathrm{l}$ of distilled water with a phytic acid hydrolysate and $200 \mu 1$ of chloroform with bovine brain extract (Sigma type I) were added. Phytic acid hydrolysate and bovine brain extract served as a carriers to minimize the loss of radiolabelled inositol phosphates and lipids during the isolation procedures. The aqueous phase was processed for inositul phosphates and the interface for protein (see below). Radioactivity of the chloroform phase was measured by liquid scintillation counting to determine the radioactivity of $\left[{ }^{3} \mathrm{H}\right]$ inositol incorporation into phosphoinositides (PtdInsPs) (Brown et al., 1984).

\section{Separation of labelled inositol phosphates}

Inositol phosphates in the aqueous phase were separated from inositol on a Dowex-1 formate column as described (Berridge et al., 1983; Dean and Beaven, 1989) with minor modifications. The column was a Pasteur capillary pipet filled with Dowex-1 formate (cross-linkage 8\%, mesh size 200-400) to a height of 25 $\mathrm{mm}$. Two hundred $\mu \mathrm{l}$ of aqueous phase diluted to a final volume of $1.5 \mathrm{ml}$ with distilled water was passed over the column which was then washed with $8 \mathrm{ml}$ of 5 $\mathrm{mM}$ myoinositol. Combined inositol phosphates were eluted with $5 \mathrm{ml}$ of $1 \mathrm{M}$ ammonium formate in $0.1 \mathrm{M}$ 
formic acid. For the separation of individual inositol phosphates, $5 \mathrm{ml}$ of $5 \mathrm{mM}$ sodium tetraborate in 60 $\mathrm{mM}$ sodium formate, $0.2 \mathrm{M}$ ammonium formate in 0.1 $\mathrm{mM}$ formic acid, $0.4 \mathrm{M}$ ammonium formate in $0.1 \mathrm{mM}$ formic acid, $1 \mathrm{M}$ ammonium formate in $0.1 \mathrm{mM}$ formic acid were applied sequentially to elute glycerophosphoinositol (GPI), inositol monophosphate (InsP), inositol bisphosphate $\left(\mathrm{InsP}_{2}\right)$ and inositol trisphosphate $\left(\operatorname{InsP}_{3}\right)$, respectively. Radioactivity of each fraction was determined by liquid scintillation counting. Columns were regenerated with $10 \mathrm{ml}$ of $1 \mathrm{M}$ sodium formate in 0.1 $\mathrm{M}$ formic acid and then rinsed with $10 \mathrm{ml}$ of distilled water; they were discarded after 5 experiments.

\section{Other procedures}

Protein content in the interface was determined by the method of Bradford (1976) against bovine serum albumin as a standard. After removing both aqueous and chloroform phases, $50 \mu \mathrm{l}$ of $1 \mathrm{~N} \mathrm{NaOH}$ was added to the remaining pellet. Following 5 days of incubation at room temperature, an aliquot was assayed.

The amount of radioactive inositol phosphates was expressed as dpm of labelled InsPs per $\mu \mathrm{g}$ protein. Similar results were obtained when InsPs were expressed as \% of total radioactive label (PtdInsPs plus InsPs) (data not shown). Results are reported as means \pm SD. Statistical significance was tested using ANOVA.

The care and use of animals reported on in this study were reviewed under grants DC-00078 and AG08885, and approved and supervised by the University of Michigan Unit on Laboratory Animal Medicine.

\section{Results}

Release of InsPs after the preincubation of the isolated intact organs with myo- $\left[{ }^{3} \mathrm{H}\right]$ inositol was 3703 $\pm 950 \mathrm{dpm} / \mu \mathrm{g}$ protein in the cochlear sensory epithelia and $4250 \pm 2076 \mathrm{dpm} / \mu \mathrm{g}$ protein in the vestibular sensory epithelia. Addition of the cholinergic agonist carbamylcholine or the $\mathrm{P}_{2}$ purinergic agonist adenosine 5'-O-(3-thiophosphate) (ATP- $y-S$ ) resulted in a concentration-dependent increase in the formation of $\left[{ }^{3} \mathrm{H}\right]$ InsPs (Fig. 1). In the cochlear sensory epithelia, increases of InsPs over controls were significant at and above $100 \mu \mathrm{M}$ carbamylcholine and at and above 20 $\mu \mathrm{M}$ ATP- $\gamma$-S. In the vestibular sensory epithelia, $1 \mathrm{mM}$ or more carbamylcholine and $200 \mu \mathrm{M}$ or more ATP- $\gamma$-S significantly increased InsPs release. Maximal stimulation was 2.1-fold and 1.9-fold for carbamylcholine in the cochlear and vestibular sensory epithelia, respectively. ATP- $\gamma$-S (200 $\mu \mathrm{M})$ caused a 8.7-fold and 4.1-fold increase in InsPs release in the cochlear and vestibular sensory epithelia, respectively.

The combined InsPs fraction included GPI, InsP, InsP $P_{2}$ and $I n s P_{3}$. After separation, the relative amounts
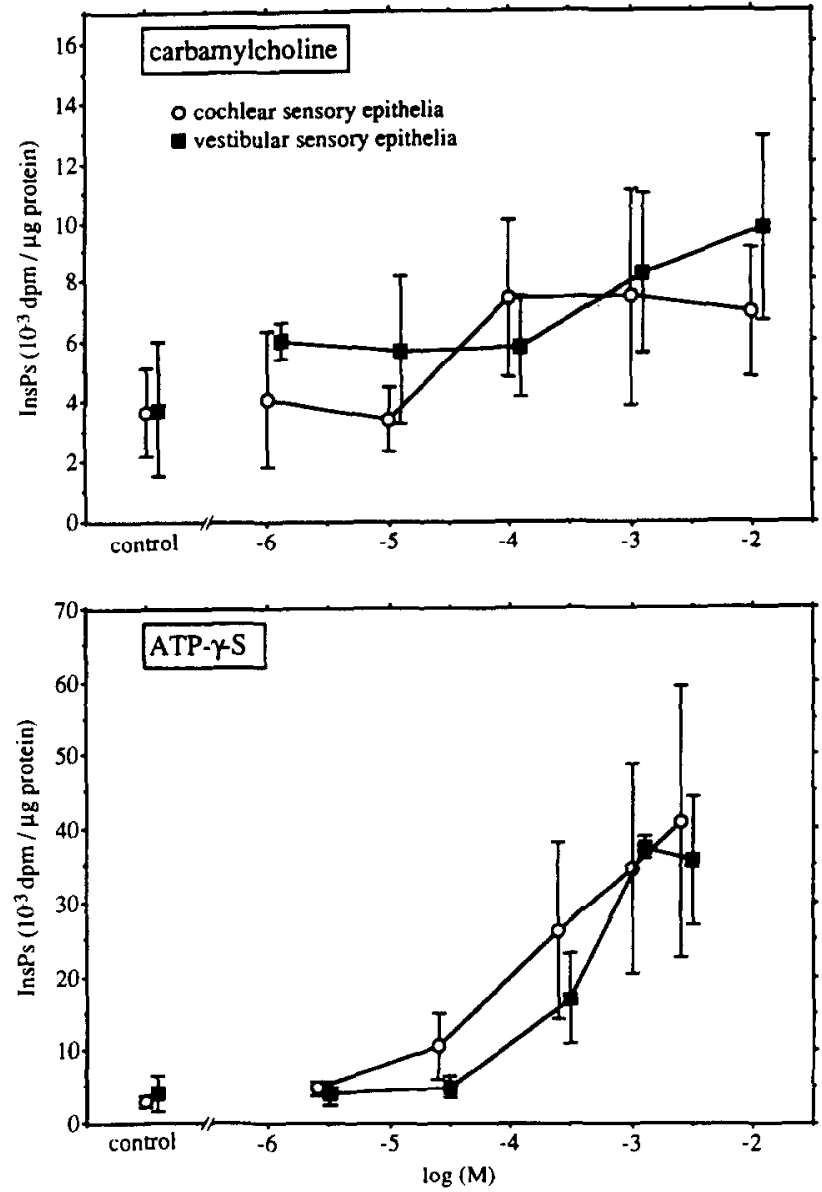

Fig. 1. Dose-response curves of InsPs release stimulated by carbamylcholine and ATP- $\gamma$-S. The cochlear and vestibular sensory epithelia were prelabelled with $16 \mu \mathrm{Ci} m y o-\left[{ }^{3} \mathrm{H}\right]$ inositol and incubated with $0.01 \sim 10 \mathrm{mM}$ carbamylcholine chloride or $0.002 \sim 2 \mathrm{mM}$ ATP- $y-S$ for $30 \mathrm{~min}$ as described in Materials and Methods. Open circles represent InsPs release in the cochlear sensory epithelia and closed squares represent those in the vestibular sensory epithelia. Each point is the mean \pm SD of $4 \sim 7$ independent experiments. In the cochlear sensory epithelia, increases of InsPs over controls were significant $(\mathrm{p}<0.05)$ at and above $100 \mu \mathrm{M}$ carbamylcholine and at and above $20 \mu \mathrm{M}$ ATP- $\gamma$-S. In the vestibular sensory epithelia, 1 $\mathrm{mM}$ or more carbamylcholine and $200 \mu \mathrm{M}$ or more ATP- $\gamma$-S significantly $(p<0.05)$ increased InsPs relcasc.

of GPI, InsP, InsP $\mathrm{P}_{2}$ and $\mathrm{InsP}_{3}$ in controls were determined to be $36.0 \pm 15.0 \%, 37.6 \pm 18.3 \%, 10.5 \pm 4.7 \%$ and $16.0 \pm 6.1 \%$ in the cochlear sensory epithelia and $22.8 \pm 8.0 \%, 48.0 \pm 5.9 \%, 13.8 \pm 5.9 \%$ and $15.3 \pm 6.9 \%$ in the vestibular sensory epithelia, respectively. Carbamylcholine ( $1 \mathrm{mM})$ significantly increased InsP and InsP $\mathrm{P}_{3} 2.7$-fold and 2.3-fold in the cochlear and 2.5-fold and 2.0-fold in the vestibular sensory epithelia, respectively. On the other hand, ATP- $\gamma$-S $(200 \mu \mathrm{M})$ significantly increased InsP, InsP ${ }_{2}$ and $\operatorname{InsP}_{3}$ release 13.0-fold, 5.1-fold and 4.2-fold in the cochlear and 8.3-fold, 3.6fold and 4.9-fold in the vestibular sensory epithelia, respectively (Fig. 2). 

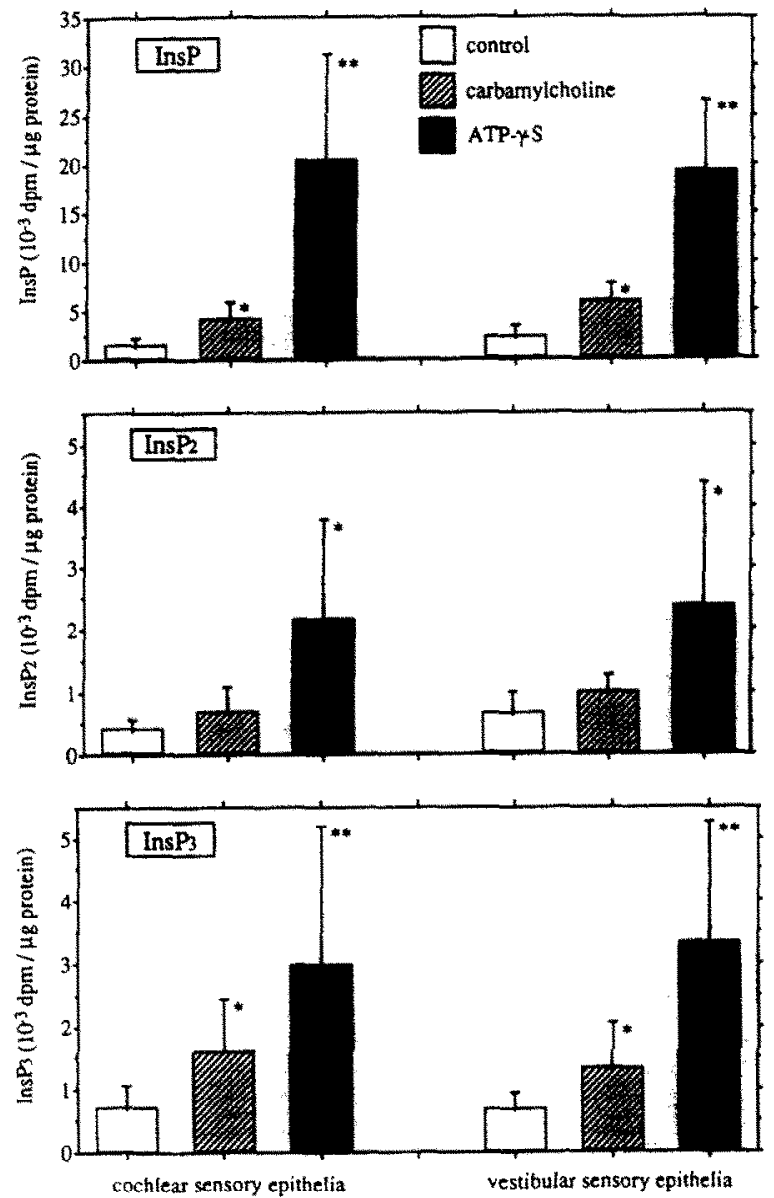

Fig. 2. Effect of carbamylcholine and ATP- $\boldsymbol{S}_{\star} \mathrm{S}$ on $\operatorname{lns} \mathrm{P}, \operatorname{Ins} \mathrm{P}_{2}$ and Ins $P_{3}$. The cochlear and vestibular sensory epithelia were prelabelled and incubated with $1 \mathrm{mM}$ carbamylcholine chloride or $200 \mu \mathrm{M}$ ATP- $\gamma-S$ for $30 \mathrm{~min}$ as described in Materials and Methods. Each figure is the mean $\pm S D$ of 6 independent experiments. Statistical significance of differences from controls were determined by ANOVA $(*, 0.01<P<0.05 * *, P<0.01)$.

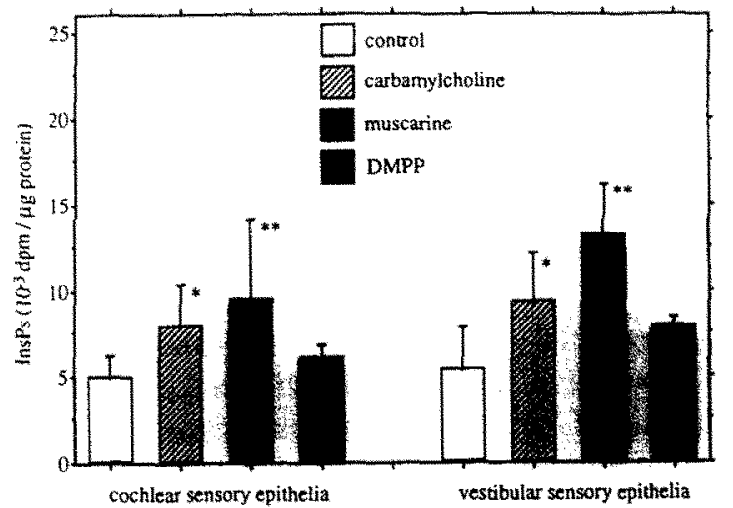

Fig. 3. Effect of the muscarinic cholinergic agonist muscarine and the nicotinic cholinergic agonist DMPP on InsPs release. The cochlear and vestibular sensory epithelia were prelabelled and incubated with $1 \mathrm{mM}$ muscarine or $30 \mu \mathrm{M}$ DMPP for $30 \mathrm{~min}$ as described in Materials and Methods. Each figure is the mean $\pm S D$ of $4 \sim 5$ independent experiments.

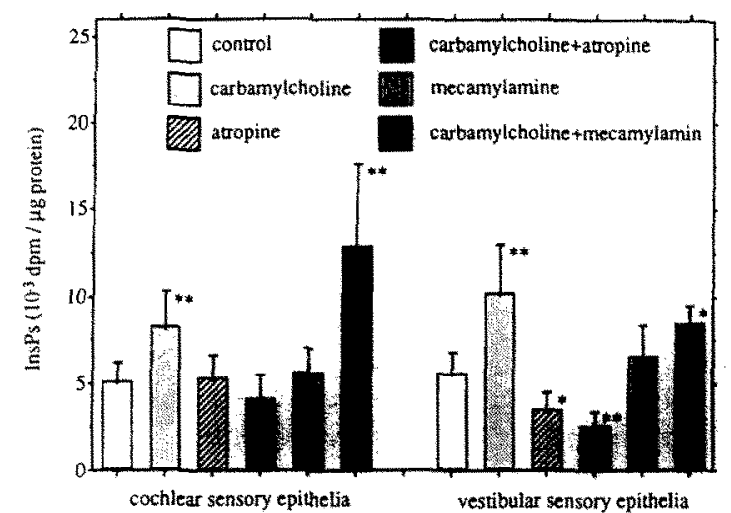

Fig. 4. Effect of the muscarinic cholinergic antagonist atropine and the nicotinic cholinergic antagonist mecamylamine on InsPs release. The cochlear and vestibular sensory epithelia were prelabelled and incubated with $10 \mu \mathrm{M}$ atropine sulfate or $10 \mu \mathrm{M}$ mecamylamine with or without $1 \mathrm{mM}$ carbamylcholine chloride for $30 \mathrm{~min}$ as described in Materials and Methods. Each figure is the mean $\pm S D$ of $4 \sim 5$ independent experiments.

The subtype of cholinergic receptor coupled to InsPs release was determined by the use of selected muscarinic or nicotinic cholinergic agonists and antagonists. The muscarinic cholinergic agonist muscarine (1 $\mathrm{mM}$ ) acted similarly to $1 \mathrm{mM}$ carbamylcholine, causing a 1.9-fold and 1.4-fold increase of InsPs in the cochlear and vestibular sensory epithelia, respectively. In contrast, the nicotinic cholinergic agonist 1,1-dimethyl-4 phenylpiperadinium (DMPP, $30 \mu \mathrm{M}$ ) did not significantly affect InsPs release in these tissues (Fig. 3).

The muscarinic cholinergic antagonist atropine (10 $\mu \mathrm{M}$ atropine sulfate) completely suppressed stimulated InsPs release induced by $1 \mathrm{mM}$ carbamylcholine in both tissues, while the nicotinic cholinergic antagonist mecamylamine $(10 \mu \mathrm{M})$ did not. Atropine and mecamylamine alone had no effect on unstimulated InsPs accumulation in the cochlear sensory epithelia.

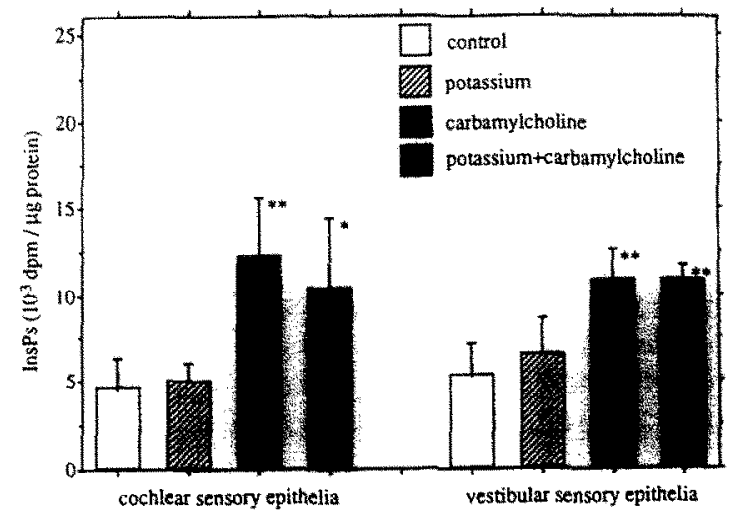

Fig. 5. Effect of potassium-induced depolarization on InsPs release. The cochlear and vestibular sensory epithelia were prelabelled and incubated with $50 \mathrm{mM} \mathrm{KCl}$ with or without $1 \mathrm{mM}$ carbamylcholine chloride for $30 \mathrm{~min}$ as described in Materials and Methods. Each figure is the mean $\pm S D$ of 4 independent experiments. 


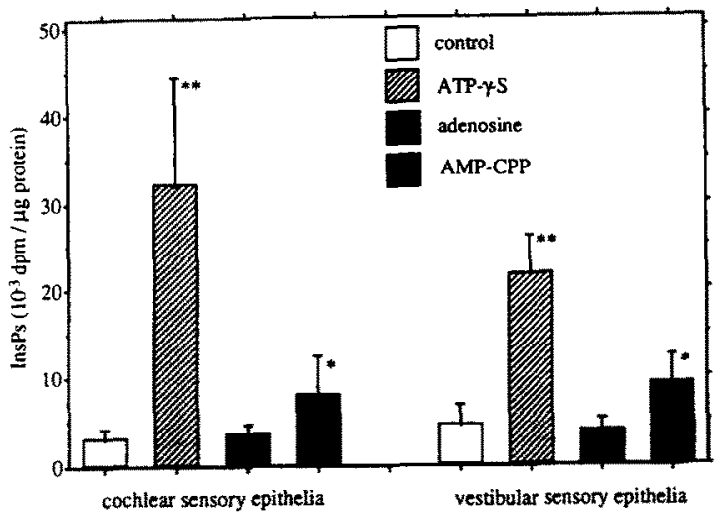

Fig. 6. Effect of the $P_{2}$ purinergic agonists ATP- $y-S$ and AMP-CPP and the $P_{1}$ purinergic agonist adenosine on InsPs release. The cochlear and vestibular sensory cpithelia were prelabelled and incubated with $200 \mu \mathrm{M}$ ATP- $\gamma-\mathrm{S}, 200 \mu \mathrm{M}$ AMP-CPP or $200 \mu \mathrm{M}$ adenosine for $30 \mathrm{~min}$ as described in Materials and Methods. Each figure is the mean $\pm S D$ of 4 independent experiments.

In the vestibular sensory epithelia, however, atropine significantly suppressed both unstimulated and carbamylcholine-stimulated InsPs release (Fig. 4).

The effect of potassium depolarization on carbamylcholine-stimulated InsPs release was determined by incubating cochlear and vestibular tissues with $50 \mathrm{mM}$ $\left[\mathrm{K}^{+}\right]$for $30 \mathrm{~min}$ with or without carbamylcholine. Neither unstimulated nor carbamylcholine-stimulated InsPs release was affected by potassium depolarization (Fig. 5).

Purinergic receptor agonists were used in an effort to determine the subtype of purinergic receptor coupled to InsPs release. Although the $\mathrm{P}_{2}$ purinergic agonist a,b-methyladenosine 5'-diphosphate (AMP-CPP, $200 \mu \mathrm{M}$ ) increased InsPs release 2.6-fold in the cochlear sensory epithelia and 2.0 -fold in the vestibular sensory epithelia, its effect was significantly smaller than that of ATP- $\gamma$-S (10.2-fold and 4.7-fold). In addition, InsPs release was not stimulated by the $P_{1}$ purinergic agonist adenosine (200 $\mu \mathrm{M})$ (Fig. 6).

\section{Discussion}

In both the cochlear and vestibular sensory epithelia, the InsP $\mathrm{P}_{3}$ second messenger system appears to be linked to muscarinic cholinergic and $P_{2} y$ purinergic receptors. In both organs, the cholinergic agonist carbamylcholine and the $\mathrm{P}_{2}$ purinergic agonist ATP- $\gamma-\mathrm{S}$ elicited a concentration-dependent increase in InsPs release with a much higher effect induced by ATP- $\gamma-\mathrm{S}$. These findings extend our previous results in the organ of Corti of the guinea pig (Niedzielski and Schacht, 1991, 1992; Niedzielski et al., 1992) to the rat and suggest the existence of a similar InsP $\mathrm{P}_{3}$ second messenger system in the rat vestibule. While the magnitude of stimulation by both agonists is similar in rat and guinea pig cochlea, the amount of $\left[{ }^{3} \mathrm{H}\right]$ inositol radioactivity in the IPs fraction is considerably higher in the rat. This may reflect differences in assay conditions (aeration of the incubation buffer in the present study) or species differences in intrinsic inositol levels or lipid metabolism.

The accumulation of InsP was increased more than that of $\operatorname{InsP}_{2}$ and InsP $\mathrm{P}_{3}$ by both agonists. InsP $\mathrm{P}_{3}$, the immediate second messenger produced from PtdIns $\mathrm{P}_{2}$, is rapidly metabolized primarily yielding $\operatorname{InsP}_{2}$ and InsP as intermediates and, finally, free inositol. However, InsPs can be trapped for analysis at the level of InsP by the use of $\mathrm{LiCl}$, an inhibitor of inositol monophosphatase. InsP and $\mathrm{InsP}_{2}$ can also be derived directly from hydrolysis of phosphatidylinositol and phosphatidylinositol monophosphate (Majerus et al., 1988). A previous study of the whole cochlea (Guiramand et al., 1990) had failed to identify any increase of Ins $_{3}$ in response to carbamylcholine leaving the possibility open that InsPs were not derived from PtdInsP $\mathrm{P}_{2}$. The significant increase of $\operatorname{Ins}_{3}$ seen in the present investigation suggests that the primary pathway of $\operatorname{Ins} P_{3}$ generation from $P$ tdIns $P_{2}$ is present in the cochlear and vestibular sensory epithelia.

Potassium depolarization is known to potentiate carbamylcholine-stimulated InsPs release in the brain (Eva and Costa, 1986; Challis and Nahorski, 1991). It has been suggested that depolarization enhances the coupling of muscarinic receptors and PLC by activating the GTP-binding protein (G-protein) (Eva and Costa, 1986). In our study, however, potassium depolarization neither affected unstimulated nor carbamylcholinestimulated InsPs release in the cochlear and vestibular sensory epithelia. This difference may be related to the type of G-protein associated with the receptor. Although several classes of G-protein have been identified in the organ of Corti (Canlon et al., 1991; Tachibana et al., 1992), nothing is known about the type of G-protein coupled to the $\operatorname{InsP}_{3}$ second messenger system in the inner ear.

The function of the vestibular efferent system remains speculative. It may regulate the sensitivity of the hair cells during spontaneous or reflex-induced movement like the muscle spindle under $\gamma$-neuron control. In addition, this system may be related to vestibular habituation or compensation (Goldberg and Fernandez, 1975. for review). Although acetylcholine is assumed to be a neurotransmitter in the vestibular efferent system as in the cochlea (Klinke, 1986; Schwartz et al., 1986; Anniko and Arnold, 1991), little is known about the receptors linked to the vestibular efferent system. Electrical stimulation of vestibular efferent fibers produces both inhibition and facilitation of the afferent activity (Dechesne and Sans, 1980; Goldberg and Fernandez, 1980). It is not clear whether these two 
types of actions use different neurotransmitter mechanisms. However, the stimulation by cholinergic agonists also produces both inhibition and facilitation of the afferent activity, suggesting that acetylcholine is a putative neurotransmitter for both types of efferent effects (Housley et al., 1990). Recently, a study using $\alpha$ bungarotoxin binding suggested the presence of nicotinic cholinergic receptors in the frog vestibular sensory epithelia (Thornhill, 1991), and mRNA of the nicotinic cholinergic receptor subunit was shown to be expressed in vestibular hair cells (Wachym et al., 1991). However, the inhibitory effect of atropine on IPSPs elicited by electrical stimulation of the frog sacculus suggests the additional presence of muscarinic cholinergic receptors (Sugai et al., 1992). Our results support the existence of muscarinic cholinergic receptors in the vestibular sensory epithelia.

The differential response of InsPs release to atropine in the vestibular sensory epithelia is interesting. In the cochlear sensory epithelia, carbamylcholine-induced InsPs release was completely blocked by atropine, but atropine had no effect on unstimulated InsPs release. These results agree with those in the whole rat cochlea (Guiramand et al., 1989) and in the organ of Corti of guinea pig (Niedzielski and Schacht, 1990). In contrast, atropine lowered both the unstimulated and stimulated InsPs release in the vestibular sensory epithelia. This suggests that the muscarinic cholinergic receptor in the vestibular sensory epithelia could be stimulated by endogenous acetylcholine during the experiment. Even in the resting state, endogenous acetylcholine might be released constantly to regulate the spontaneous activity of vestibular afferent system.

ATP may serve as a neuromodulator in the central and peripheral nervous system by increasing or decreasing the release of other neurotransmitters, or by modulating their action (Gordon, 1986). Purinergic receptors are classified into $P_{1}$ and $P_{2}$ receptors which are further divided into $P_{2} x$ and $P_{2} y$ receptor subtypes based on their affinity for different purinergic agonists (Burnstock, 1990, for review). The order of potency of agonists for InsPs release obtained in this study, ATP$\gamma$-S $>\alpha, \beta$-methylene-ATP $>$ adenosine, corresponds to that of a $\mathrm{P}_{2} \mathrm{y}$ purinergic receptor. This result is in agreement with the studies that demonstrate $P_{2} y$ receptors coupled to PLC in nerve cells (Ehrlich et al., 1988; Fisher and Landon, 1991; Kastritsis et al., 1992). While ATP is known to coexist with acetylcholine in the autonomic nervous system (Burnstock, 1981), there is no anatomical evidence for purinergic receptors in the cochlear and vestibular sensory epithelia. Thus, a role for ATP and ATP-coupled second messengers remains to be established.

Finally, the question arises as to the physiological role of the $\operatorname{Ins}_{3} \mathrm{P}_{3}$ second messenger system in the inner ear. The cholinergic control points to the efferents where both the lateral and the medial system may utilize this second messenger for an as yet unknown aspect of their function. Both muscarinic cholinergic and purinergic receptor agonists increase intraccllular calcium concentrations in isolated outer hair cells (Shigemoto and Ohmori, 1990; Nakagawa et al., 1990). Such an effect might link the phosphoinositides with the regulation of calcium levels and therefore, possibly, to some aspects of the control and modulation of 'slow motility' (Dulon and Schacht, 1992). Acetylcholine has indeed been linked to inositol phosphates in outer hair cells of the guinea pig (Kakehata et al., 1992). On the other hand, some hair cell responses to this neurotransmitter, for example, hyperpolarization, may be mediated by a nicotinic-like receptor (Housley and Ashmore, 1991).

Several anatomical and physiological observations have led to the speculation that the vestibular hair cells also possess active motile properties regulated by intracellular calcium mobilization (Sans et al., 1989; Zenner et al., 1990; Valat et al., 1991, Lepyre and Cazals, 1991). Calcium in vestibular hair cells may, then, likewise be under regulation by phoshoinositides and $\operatorname{InsP}_{3}$. However, such an action may at best be one of many potential physiological functions of this second messenger system in the cochlea and the vestibule. The precise role of phosphoinositides, calcium and protein phosphorylation in inner ear physiology remains to be established.

\section{Acknowledgements}

The authors wish to thank Dr. Donald E. Coling and Dr. Andrew S. Niedzielski for their thoughtful suggestions and discussions for this study. This work was supported by the grants DC-00078 and AG-08885 from the National Institute of Health.

\section{References}

Anniko, M. and Arnold, W. (1991) Acetylcholine receptor localization in human adult cochlear and vestibular hair cells. Acta Otolaryngol. (Stockh.) 111, 491-499.

Bartolami, S., Guiramand, J., Lenoir, M., Pujol, R. and Kécasens, M. (1990) Carbachol-induced inositol phosphate formation during rat cochlea development. Hear. Res. 47, 229-234.

Berridge, M.J., Dawson, R.M.C., Downes, C.P., Heslop, J.P. and Irvine, R.F. (1983) Changes in the levels of inositol phosphates after agonist-dependent hydrolysis of membrane phosphoinositides. Biochem. J. 212, 473-482.

Berridge, M.J. and Irvine, R.F. (1984) Inositol triphosphate, a novel second messenger in cellular signal transduction. Nature 312 , 315-321.

Bobbin, R.P., Fallon, M., Puel, J.L., Bryant, G., Bledsoe, S.C., Zajic, G. and Schacht, J. (1990) Acetylcholine, carbachol and GABA 
induced no detectable change in the length of isolated outer hair cells. Hear. Res. 47, 39-52.

Bradford, M.M. (1976) A rapid and sensitive method for the quantitation of microgram quantities of protein utilizing the principle of protein-dye binding. Anal. Biochem. 72, 248-254.

Brown, E., Kendall, D.A. and Nahorski, S.R. (1984) Inositol phospholipid hydrolysis in rat cerebral cortical slices: I. Receptor characterisation. J. Neurochem. 42, 1379-1387.

Burnstock, G. (1981) Neurotransmitters and trophic factors in the autonomic nervous system. J. Physiol. 313, 1-35.

Burnstock, G. (1990) Overview. Purinergic mechanisms. Ann. NY. Acad. Sci. 603, 31-44.

Canlon, B. Homburger, V., and Bockaert, J. (1991) The identification and localization of the guanine nucleotide protein Go in the auditory system. Eur. J. Neurosci. 3, 1338-1342.

Challis, R.A.J. and Nahorski, S.R. (1991) Depolarization and agonist-stimulated changes in inositol 1,4,5-triphosphate and inositol 1,3,4,5-tetrakisphosphate mass accumulation in rat cerebral cortex. J. Neurochem. 57, 1042-1051.

Dean, N.M and Beaven, M.A (1989) Methods for the analysis of inositol phosphate. Anal. Biochem. 183, 199-209.

Dechesne C. and Sans, A. (1980) Control of the vestibular nerve activity by the efferent system in the cat. Acta Otolaryngol. 90, 82-85.

Drescher, D.G., Upadhyay, S., Wilcox, E. and Fex, J. (1992) Analysis of muscarinic receptor subtypes in the mouse cochlea by means of the polymerase chain reaction. J. Neurochem. 59, 765-767.

Dulon, D. and Schacht, J. (1992) Motility of cochlear outer hair cells. Am. J. Otol. 13, 108-112.

Dulon, D., Zajic, G. and Schacht, J. (1990) Increasing intracellular free calcium induces circumferential contractions in isolated cochlear outer hair cells. J. Neurosci. 10, 1388-1397.

Dulon, D., Zajic, G. and Schacht, J. (1993) InsP ${ }_{3}$ releases intracellular stored calcium in Deiters' cells of the organ of Corti. Abstr. Assoc. Res. Otolaryngol. 16, 117.

Ehrlich, Y.H., Snider, R.M., Kornecik, E., Garfield, M.G. and Lenox, R.H. (1988) Modulation of neuronal signal transduction systems by extracellular ATP.J. Neurochem. 50, 295-301.

Eva, C. and Costa, E. (1986) Potassium ion facilitation of phosphinositide turnover activation by muscarinic receptor agonists in rat brain. J. Neurochem. 46, 1429-1435.

Fisher, S.K. and Landon, R.E. (1991) Identification of multiple phosphoinositide-linked receptors on human SK-N-MC neuroepithelioma cells. J. Neurochem. 57, 1599-1608.

Flock, A., Flock, B. and Ulfendahl, M. (1986) Mechanisms of movement in outer hair cells and a possible structural basis. Arch. Otorhinolaryngol. 243, 83-90.

Goldberg, J.M. and Fernández, C. (1975) Vestibular mechanisms. Ann. Rev. Physiol. 37, 129-162.

Goldberg, J.M. and Fernández, C. (1980) Efferent vestibular system in the squirrel monkey: anatomical location and influence on afferent activity. J. Neurophysiol. 43, 986-1025.

Gordon, J.L. (1986) Extracellular ATP: effects, sources and fate. Biochem. J. 233, 309-319.

Guiramand, J., Mayat, E., Bartolami, S., Lenoir, M., Rumigny, J.-F., Pujol, R. and Récasens, M. (1990) A M muscarinic receptor coupled to inositol phosphate formation in the rat cochlea? Biochem. Pharmacol. 39, 1913-1919.

Housley, G.D. and Ashmore, J.F. (1991) Direct measurement of the action of acetylcholine on isolated outer hair cells of the guinea pig cochlea. Proc. R. Soc. Lond. B244, 161-167.

Housley, G.D., Norris, C.H. and Guth, P.S. (1990) Cholinergically-induced changes in outward currents in hair cells isolated from the semicircular canal of the frog. Hear. Res. 43, 121-133.

Kakehata, S., Nakagawa, T., Akaike, N. and Takasaka, T. (1992) ACh activates inositol phosphate cascade via a PTX-sensitive
G-protein in dissociated outer hair cells of guinea-pig cochlea. Proc. Sendai Symp. 2, 25-29.

Kastritsis, C.H.C., Salm, A.K. and McCarthy, K. (1992) Stimulation of the $\mathrm{P}_{2} \mathrm{y}$ purinergic receptor on type $\mathrm{I}$ astroglia results in inositol phosphate formation and calcium mobilization. J. Neurochem. 58, 1277-1284.

Klinke, R. (1986) Neurotransmission in the inner ear. Hear. Res. 22, 235-243

LePeyre, P.N.M. and Cazals, Y. (1991) Guinea pig vestibular type I hair cells can show reversible shortening. J. Vest. Res. 1, 241-250.

Majerus, P.W., Connolly, T.M., Bansal, V.S., Inhorn, R.C., Ross, T.S. and Lips, D.L. (1988) Inositol phosphates: synthesis and degradation. J. Biol. Chem. 263, 3051-3054.

Nakagawa, T., Akaike, N., Kimitsuki, T., Komune, S. and Arima, T. (1990) ATP-induced current in isolated outer hair cells of guinea pig cochlea. J. Neurophysiol. 3, 1068-1074.

Niedzielski, A.S. and Schacht, J. (1991) Phospholipid metabolism in the cochlea: Differences between base and apex. Hear. Res. 57, 107-112.

Niedzielski, A.S., Ono, T. and Schacht, J. (1992) Cholinergic regulation of the phosphoinositide second messenger system in the guinea pig organ of Corti. Hear. Res. 59, 250-254.

Niedzielski, A.S. and Schacht, J. (1992) $P_{2}$ purinoceptors stimulate inositol phosphate release in the organ of Corti. Neuro Report 3 , 273-275.

Nishizuka, Y. (1984) Turnover of inositol phospholipids and signal transduction. Science 225, 1365-1370.

Ogawa, K. and Schacht, J. (1993) Effects of aging on receptor-mediated release of inositol phosphates in the organ of Corti and vestibule of the rat. Abst. Assoc. Res. Otolaryngol. 16, 91.

Ono, T. and Schacht, J. (1989) Acoustic stimulation increases phosphoinositide breakdown in the guinea pig cochlea. Neurochem. Int. 14, 327-330.

Orsulakova, A., Stockhorst, E. and Schacht, J. (1976) Effects of neomycin on phosphoinositide labelling and calcium binding in guinea pig inner ear tissues in vivo and in vitro. J. Neurochem. 26, 285-290.

Sans, A., Atger, P., Cavadore, C. and Cavadore, J.C. (1989) Immunocytochemical localization of myocin, tropomyocin and actin in vestibular hair cells of human fetuses and cats. Hear. Res. 40, 117-126.

Schacht, J. and Zenner, H.P. (1986) The phosphoinositide cascade in isolated outer hair cells: possible role as second messenger for motile responses. Hear. Res. 22, 94.

Schacht, J. and Zenner, H.-P. (1987) Evidence that phosphoinositides mediate motility in cochlear outer hair cells. Hear. Res. 31, $155-160$.

Schwarz, D.W.F., Satoh, K., Schwarz, I.E., Hu, K. and Fibiger, H.C. (1986) Cholinergic innervation of the rat's labyrinth. Exp. Brain Res 64, 19-26.

Shigemoto, T. and Ohmori, H. (1990) Muscarinic agonists and ATP increase the intracellular calcium concentration in chick cochlear hair cells. J. Physiol. 420, 127-148.

Slepecky, N., Ulfendahl, M. and Flock Å. (1988) Shortening and elongation of isolated outer hair cells in response to application of potassium gluconate, acetylcholine and cationized ferritin. Hear. Res. 34, 119-126.

Sugai, T., Yano, J., Sugitani, M. and Ooyama, H. (1992) Actions of cholinergic agonists and antagonists on the efferent synapse in the frog sacculus. Hear. Res. 61, 56-64.

Tachibana, M., Morioka, H., Machino, M., Oshima, W., Mizukoshi, F., Mizukoshi, O. and Yoshioka T. (1984) Localization of triphosphoinositides in the cochlea - An electronmicroscopic immunocytochemical study. Histochemistry $81,157-160$.

Tachibana, M., Wilcox, E., Yokotani, N., Schneider, M. and Fex, J. (1992) Selective amplification and partial sequencing of cDNAs 
encoding $G$ protein a subunits from cochlear tissues. Hear. Res. $62,82-88$.

Thornhill, R.A. (1991) Cholinergic nicotinic receptors in the vestibular epithelia. Brain Res. 561, 174-176.

Valat, J., Griguer, C., Lehouelleur, J. and Sans, A. (1991) Motile responses of isolated guinea pig vestibular hair cells. Neurosci. Lett. 127, 231-236.

Wackym, P.A., Popper, P., Ward, P.H. and Micevych, P.E. (1991) Cell and molecular anatomy of nicotinic acetylcholine receptor subunits and calcitonin gene-related peptide in the rat vestibular system. Otolaryngol. Head Neck Surg. 105, 493-510.
Wang, S. and Schacht, J. (1990) Insulin stimulates protein synthesis and phospholipid signaling systems but does not regulate glucose uptake in the inner ear. Hear. Res. 47, 53-62.

Zenner, H.P. (1986) Motile responses in outer hair cells. Hear. Res. 22, 83-90.

Zenner, H.P., Zimmermann, U. and Gitter, A.H. (1990) Cell potential and motility of isolated mammalian vestibular sensory cells. Hear. Res. 50, 289-294. 